\title{
SOME CHARACTERISTICS OF RUN-OFF IN THE ROCKY MOUNTAIN REGION.
}

\author{
By Robert Follansbee.
}

\section{BASIS OF REPORT.}

For the last nine years the United States Geological Survey has made a special study of the run-off of mountain streams, particularly in Colorado and Wyoming. The gradual installation of water-stage recorders on the larger streams has made available sufficient data to permit a study of the characteristics of these streams. During this period 40 or more stations, located in the mountains and above practically all diversions, have been maintained for periods ranging from two to eight years or more, and the records thus obtained, together with studies of the topography of the drainage basins, form the basis of this report.

\section{COMMON CHARACTERISTICS OF RUN-OFF.}

All streams that rise in the Rocky Mountains have the same characteristics of flow. In the spring of the year they have a highwater period, due to the melting of the mountain snows, and after the snow disappears the discharge decreases rapidly until it reaches a stage where the chief source of supply is the ground water. From that time on the decrease is more gradual, the flow diminishing with the decrease in the discharge of ground water. This decrease continues gradually throughout the fall and winter and usually reaches a minimum late in the winter, just before the melting snow again causes the streams to rise. Figure 8 is a typical hydrograph of a mountain stream in this region-that for the Roaring Fork at Glenwood Springs, Colo., for the year ending September 30, 1918. The discharge gradually decreased during the fall and winter, and there was no marked variation in discharge until March, when the melting of the snow at the lower altitudes first caused an increase in discharge. With increasing temperature in April the discharge increased noticeably, and the variations in flow were due to corresponding variations in temperature. The more abundant snow at the higher altitudes began to melt in May, and the melting increased until the peak was reached by the middle of June. After that time the decrease was very rapid for several weeks and then became more gradual. The rise in September was due to rainfall, which is generally not sufficient during the summer to affect the flow of the mountain streams. 
OCT. NOV. DEC. JAN. FEB. MAR. APR. MAY JUNE JULY AUG. SEPT. 510152025315101520253051015202531510152025315101520252051015202531510152025305101520253151015202530510152025315101520253151015202530

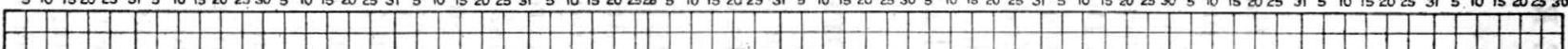

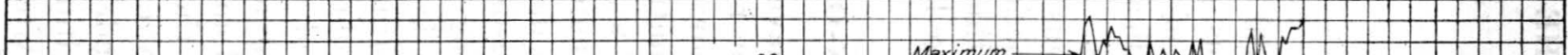

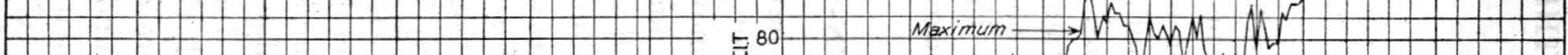

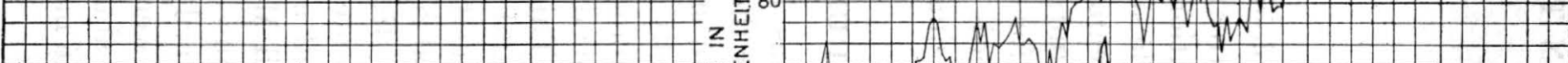

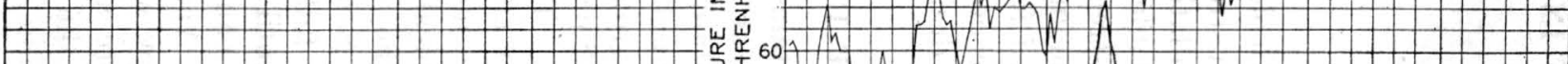

14,000
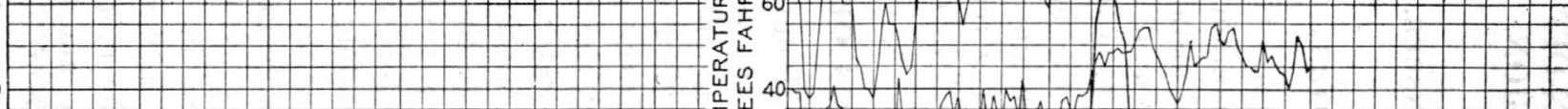

12,000

岀 10,000

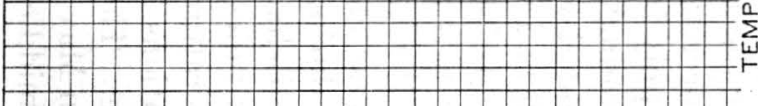

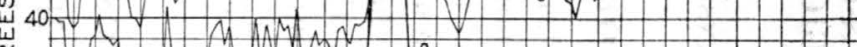
$\sum \frac{\alpha}{0}$

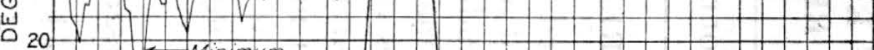
定 8,000

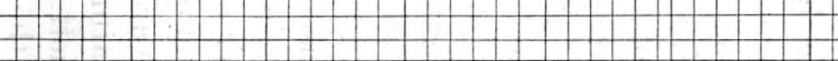

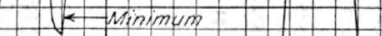

$\leq 6,000$

岁

这 4,000

I

$\frac{n}{0}$

2,000
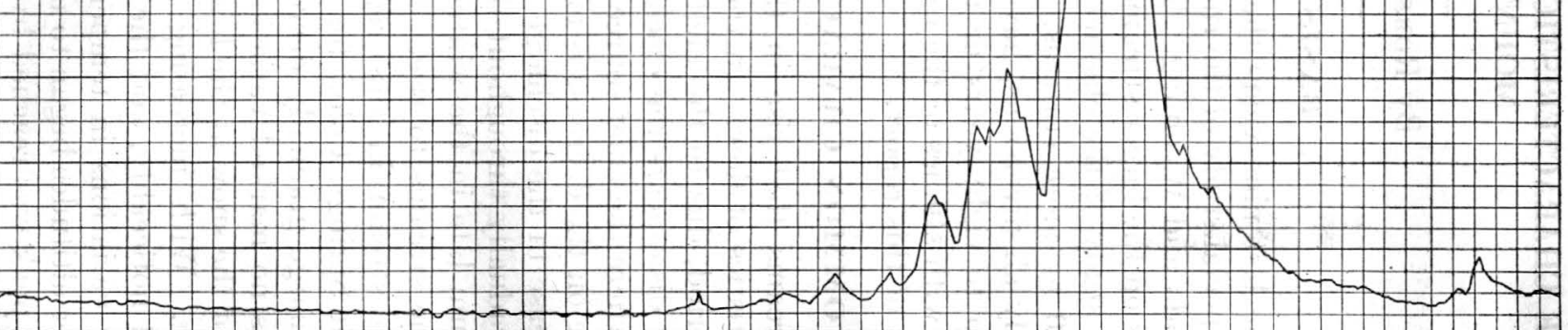

FlaURE 8.-Typical hydrograph of a Rocky Mountain stream (Roaring Fork at Glenwood Springs, Colo., for the year ending September 30, 1918). 


\section{RELATION BETWEEN TEMPERATURE AND DISCHARGE.}

General relation.-As already stated, high water is caused by the melting of the mountain snow, and the amount of rise varies directly with the temperature. In figure 8 the maximum temperatures given above the hydrograph show that a decrease in the maximum, which retards the melting of the snow, caused a corresponding decrease in discharge. Similarly, an increase in the daily maximum temperature rapidly increased the discharge until the snow had so far melted that it was no longer able to supply water as rapidly, and

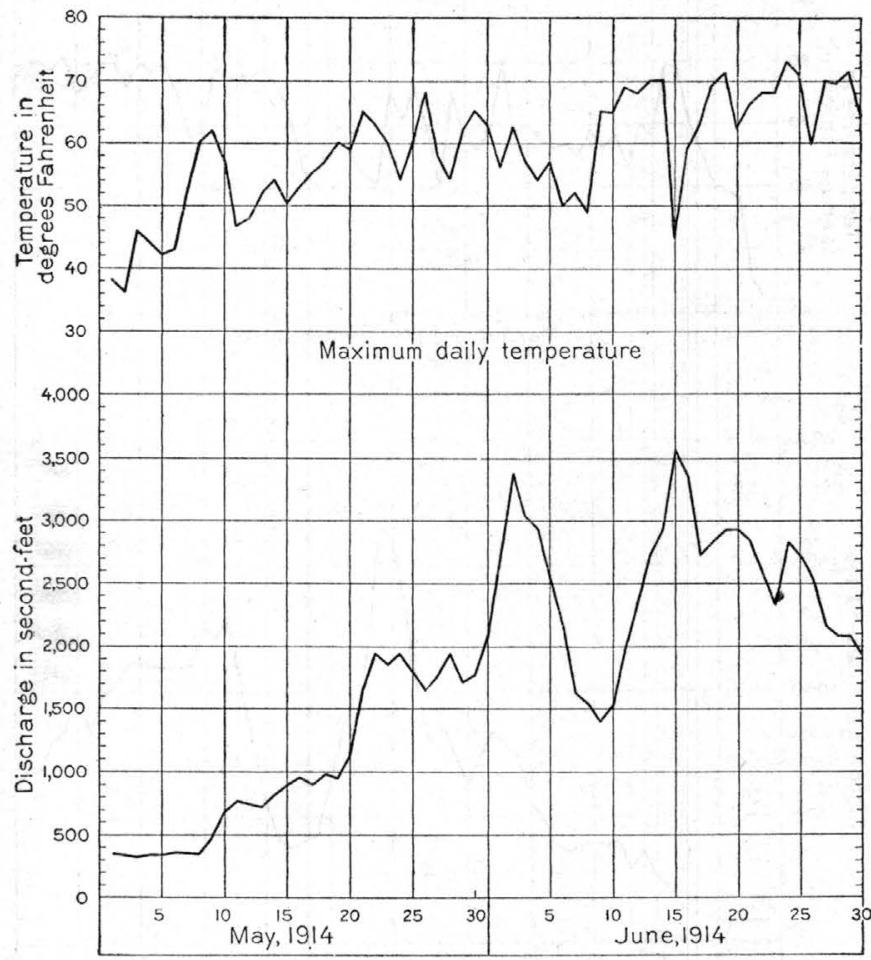

Figure 9.-High-water hydrograph for Arkansas River at Salida, Colo., showing relation between tem. perature and daily discharge.

in consequence the discharge then decreased. Beyond the time when the melting of snow with an increase in temperature causes an increase in discharge there is no relation between temperature and discharge, except during the winter. Figures 9 and 10 show strikingly the relation between temperature and discharge as brought out by hydrographs of two Colorado streams. As both hydrographs are for the same year (1914), they show the same variations in temperature and discharge. The sudden decrease in discharge between June 2 and June 10 was due to a drop in temperature. This drop occurred while a considerable amount of snow remained, and con- 
sequently the subsequent increase in temperature caused an immediate increase in discharge. Had the drop in temperature occurred after the snow had melted, there would have been no subsequent increase in discharge.

Relation between total snowfall and maximum run-off--As the discharge of the mountain streams is mainly dependent upon the mountain snow, the water equivalent of the snow that accumulates in the drainage basin determines the total run-off of the following year. If the snow falls early in the winter, it becomes compact and

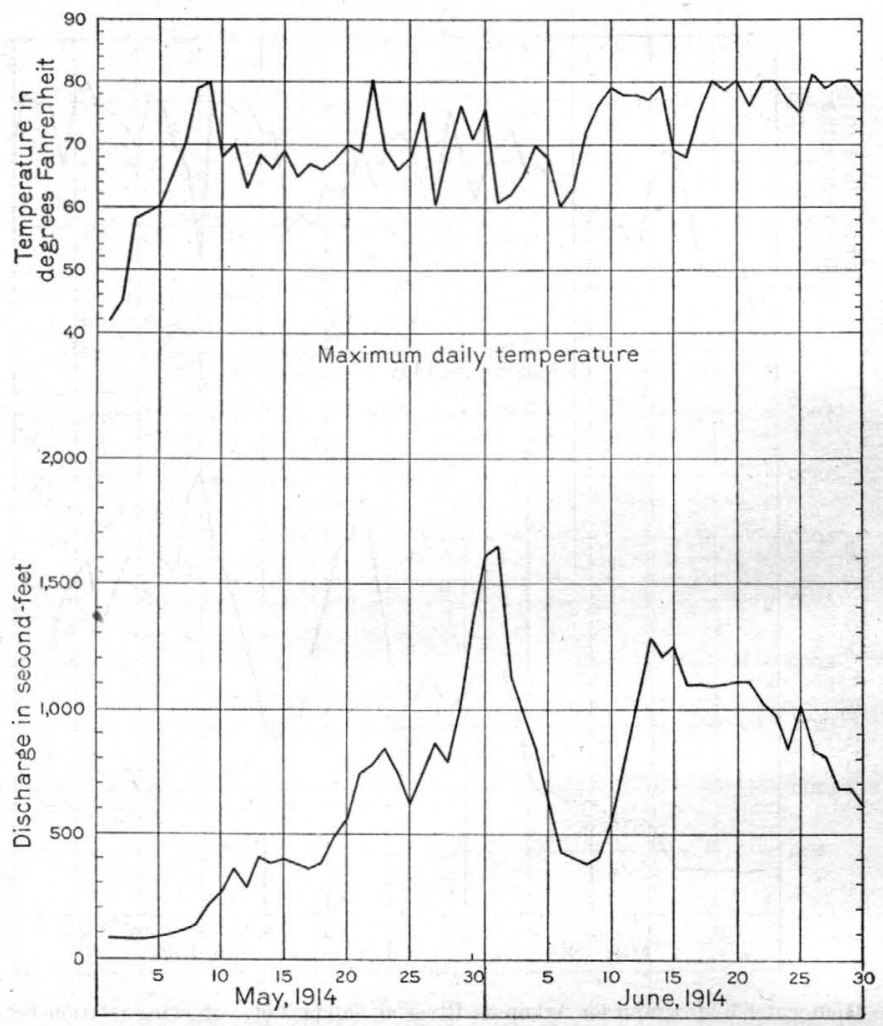

Figure 10.-High-water hydrograph for Uncompahgre River below Ouray, Colo., showing relation between temperature and daily discharge.

melts slowly in the spring, causing the high-water period to be prolonged, but the water does not reach so high a maximum stage. On the other hand, if the snow falls late in the season it is loose and melts more readily, producing a short high-water period with a high maximum discharge. The maximum discharge depends not only upon the amount of mountain snow but also upon the rapidity with which the temperature rises in the spring. Figures 11 and 12 show the high-water hydrographs for two Colorado mountain streams for 1917 and 1918, together with the maximum daily temperatures for the 
two years. In 1918 the temperature was high during the later part of May and increased rapidly during the first half of June. This caused the streams to rise rapidly to a high maximum and then recede rapidly, as the snow was soon melted. In contrast to this, in 1917 the temperature was low during the later part of May and increased but slowly during June; moreover, there were sudden drops in temperature during that period. As a result the discharge

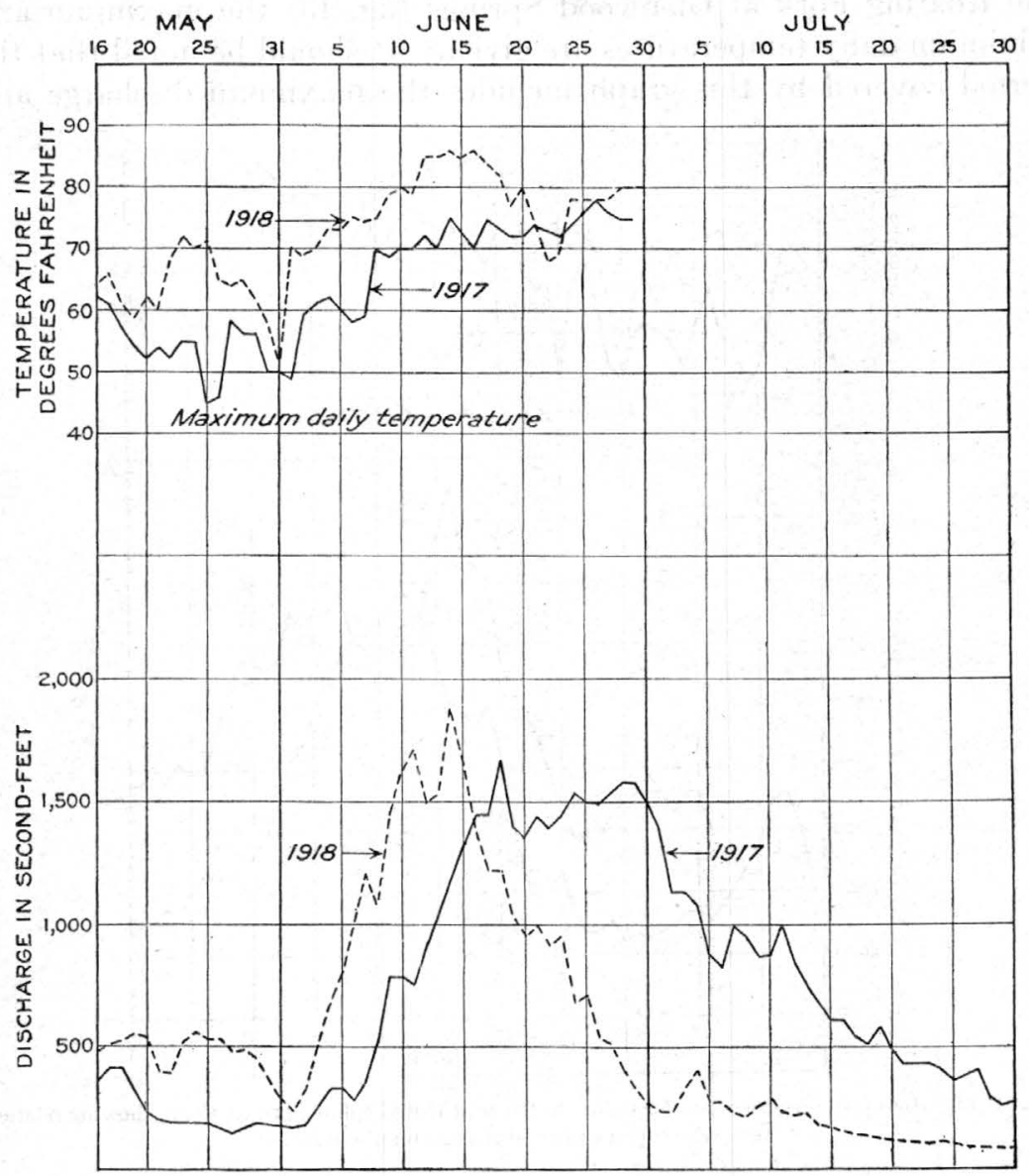

Figure 11.-High-water hydrographs for Uncompahgre River below Ouray, Colo., showing relation between temperature and maximum discharge.

increased more slowly and receded more slowly, giving a longer highwater period but one that reached a lower maximum.

Diurnal fluctuations.-At the high altitudes of the Rocky Mountains, which range from 8,000 to 14,000 feet, the temperature during the 24-hour period fluctuates $20^{\circ}$ to $30^{\circ}$ or more, and during the spring this fluctuation causes the snow to melt during the warmer part of the day but to remain frozen the remainder of the time. This in turn causes a diurnal variation in the amount of water entering 
the streams. Figures 13, 14, and 15 show the change in discharge during each 24-hour period for a week or more during high water for three typical streams. The discharge was determined from continuous gage-height graphs obtained by means of water-stage recorders. It will be seen that the hours of maximum and minimum discharge are not the same for each stream, as they depend upon the distance the melted snow has to travel before reaching the gage. For the Roaring Fork at Glenwood Springs (fig. 13) the maximum and minimum daily temperatures are given. It should be noted that the period covered by this graph includes the maximum discharge and

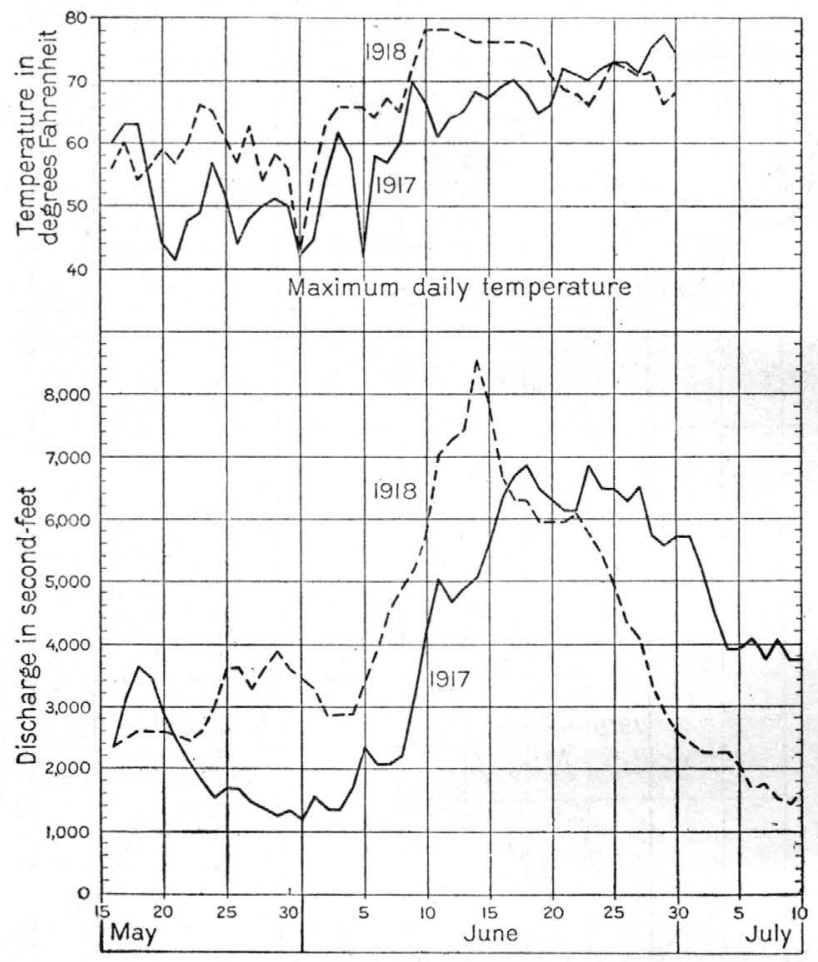

FIGURE 12.-High-water hydrographs for Colorado River at Hot Sulphur Springs, Colo., showing relation between temperature and maximum discharge.

that after June 14 the discharge decreased, although the temperatures continued high, a relation which shows that the snow had nearly disappeared.

The diurnal fluctuations are directly dependent upon the daily range of temperature up to the period of maximum discharge and also upon the increase in both maximum and minimum temperatures. Figure 16 shows the continuous discharge of Roaring Fork at Glenwood Springs from May 18 to June 10, 1919, together with the curve of maximum and minimum temperatures. From May 18 to 29 the extremes of temperature and their relation to each other remained 


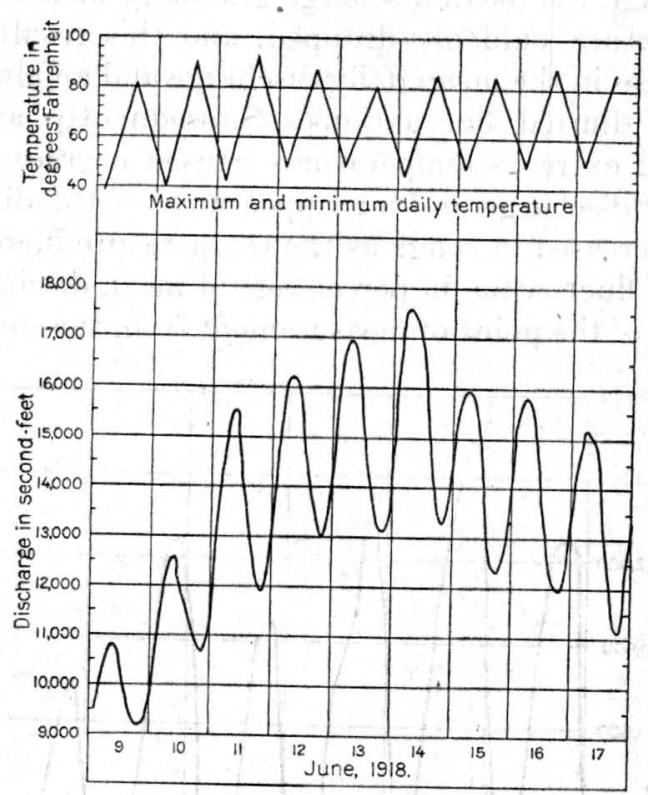

FIGURE 13.-Discharge graph of Roaring Fork at Glenwood Springs, Colo., showing diurnal fluctuations.

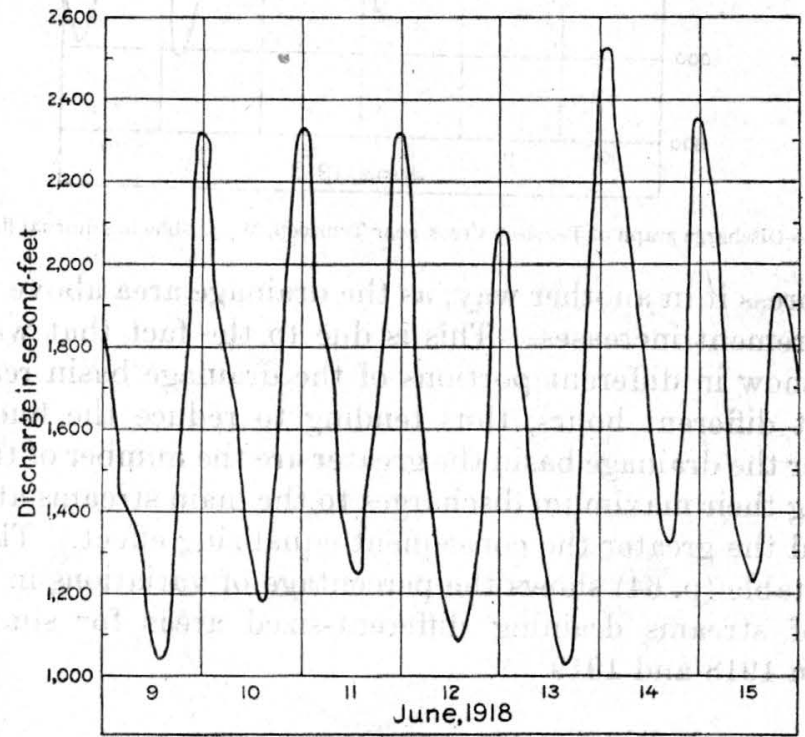

Figure 14.-Discharge graph of Uncompahgre River below Ouray, Colo., showing diurnal fluctuations. $31219^{\circ}-22 \longrightarrow 5$ 
fairly constant, and as a result the diurnal fluctuations were somewhat uniform, although the mean discharge. gradually increased. On May 30 the temperature suddenly dropped, and this resulted in an immediate decrease in the mean daily discharge and an almost complete elimination of diurnal fluctuations. Subsequently an increase in both mean and extreme temperatures caused a gradual increase in the mean daily discharge and a reappearance of the diurnal fluctuations, which increased in range as the temperature increased.

The range of fluctuation in percentage of mean discharge decreases as the distance of the point of measurement from the source increases,

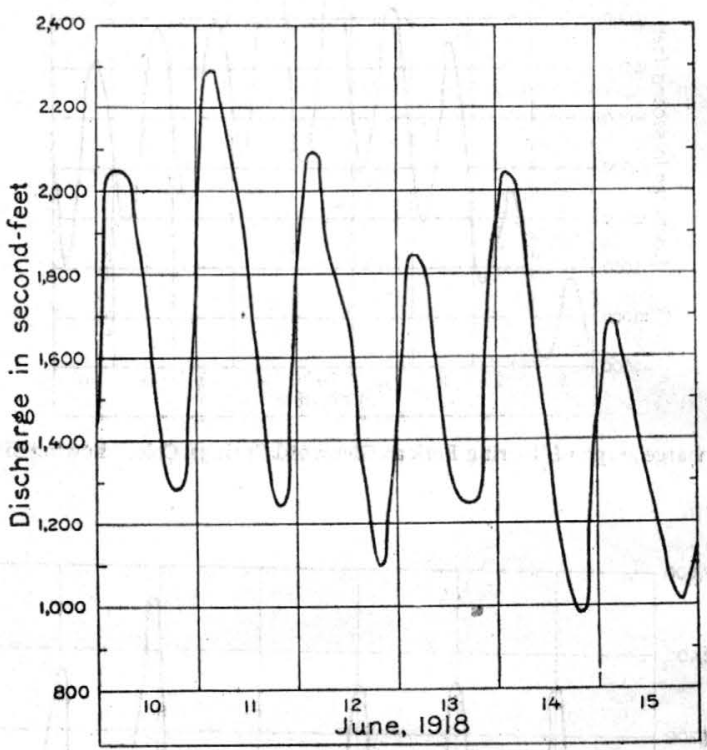

FiguRE 15.-Discharge graph of Tensleep Creek near Tensleep, W yo., showing diurnal fluctuations.

or, to express it in another way, as the drainage area above the point of measurement increases. This is due to the fact that water from melting snow in different portions of the drainage basin reaches the stream at different hours, thus tending to reduce the fluctuations. The larger the drainage basin the greater are the number of tributaries that bring their maximum discharges to the main streams at different hours and the greater the consequent equalizing effect. The accompanying table (p. 64) shows the percentage of variations in daily discharge of streams draining different-sized areas for simultaneous periods in 1918 and 1919. 


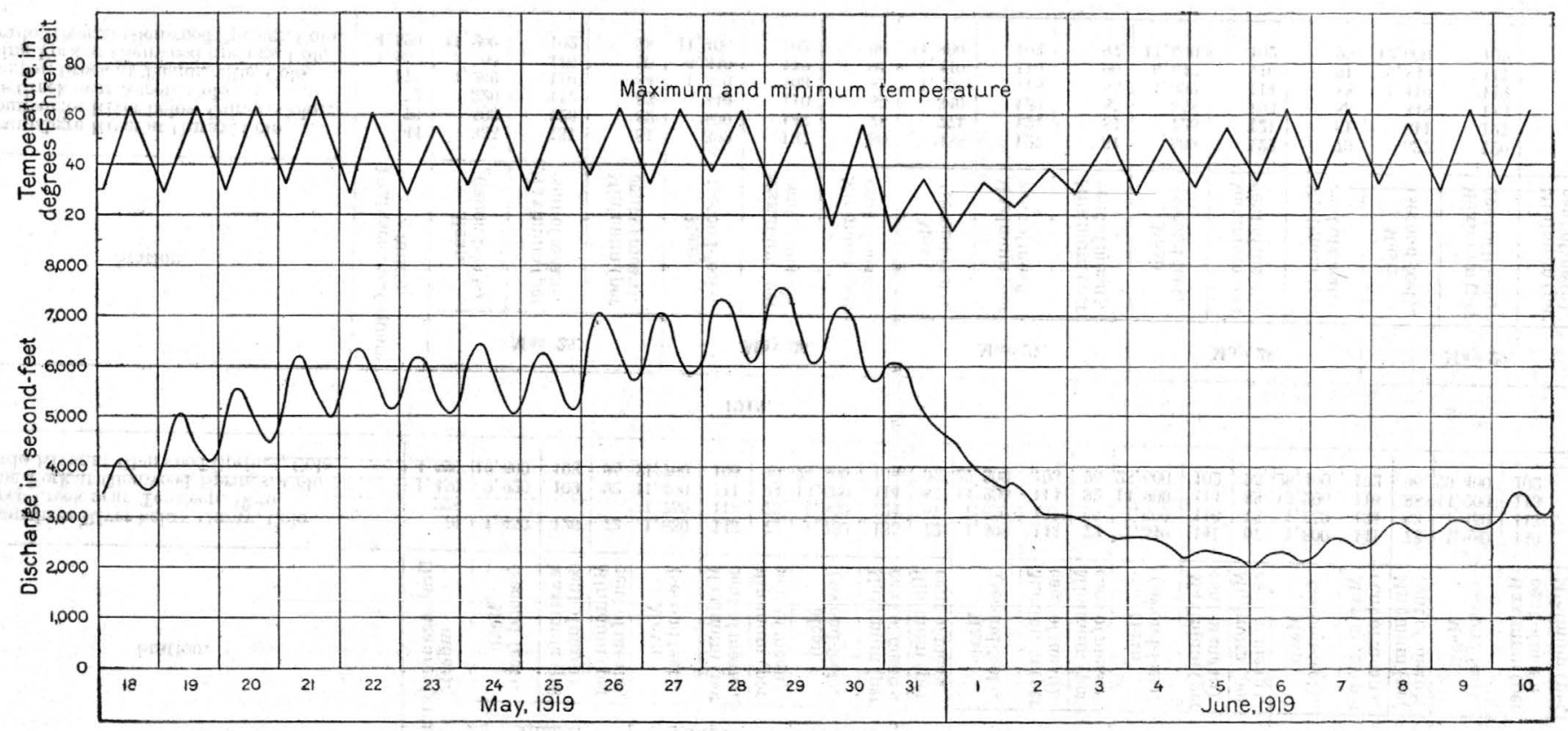

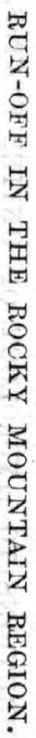

FraURE 16.-Diseharge graph of Roaring Fork at Glenwood Springs, Colo., showing relation between temperature and mean and hourly discharge. 
Percentage of variation in daily discharge for streams draining different-sized areas.

1918.

\begin{tabular}{|c|c|c|c|c|c|c|c|c|c|c|c|c|c|c|c|c|c|c|c|c|c|c|}
\hline \multirow{2}{*}{ Station. } & \multirow{2}{*}{ 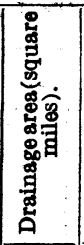 } & \multicolumn{3}{|c|}{ June 9.} & \multicolumn{3}{|c|}{ June 10.} & \multicolumn{3}{|c|}{ June 11.} & \multicolumn{3}{|c|}{ June 12.} & \multicolumn{3}{|c|}{ June 13.} & \multicolumn{3}{|c|}{ June 14.} & \multicolumn{3}{|c|}{ June 15.} \\
\hline & & 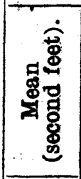 & 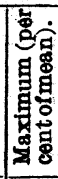 & | & 容 & 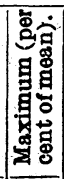 & 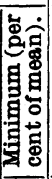 & 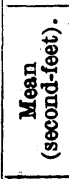 & 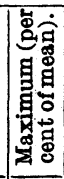 & 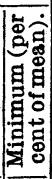 & 苞 & 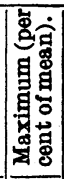 & 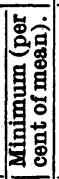 & 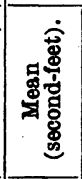 & 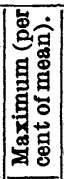 & 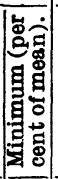 & 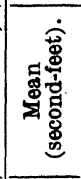 & $\mid$ & 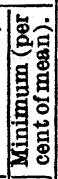 & 灾 & 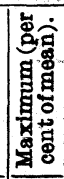 & 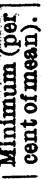 \\
\hline $\begin{array}{l}\text { Uncomplingre River below Ouray, Colo..... } \\
\text { Tensleep Creek near Tensleep, Wyo. W..... } \\
\text { Roaring Tork at Glenwood Springs, Colo.... } \\
\text { Colorad Q River at Glenwood Springs, Colo.. }\end{array}$ & $\begin{array}{r}76 \\
228 \\
1,450 \\
4,520\end{array}$ & $\begin{array}{c}1,450 \\
\dddot{9}, 920 \\
19,500\end{array} \mid$ & $\begin{array}{c}126 \\
109 \\
103\end{array}$ & $\begin{array}{l}72 \\
\dddot{92} \\
95\end{array}$ & $\begin{array}{l}1,630 \\
1,750 \\
11,400 \\
21,700\end{array}$ & $\begin{array}{l}143 \\
118 \\
111 \\
104\end{array}$ & \begin{tabular}{l|}
72 \\
73 \\
94 \\
90
\end{tabular} & $\begin{array}{r}1,730 \\
1,850 \\
13,600 \\
24,300\end{array}$ & $\begin{array}{l}135 \\
124 \\
114 \\
106\end{array}$ & $\begin{array}{l}72 \\
67 \\
87 \\
92\end{array}$ & $\begin{array}{l}1,500 \\
1,600 \\
14,200 \\
27,300\end{array}$ & $\begin{array}{l}145 \\
131 \\
114 \\
103\end{array}$ & $\begin{array}{l}72 \\
69 \\
92 \\
96\end{array}$ & $\begin{array}{r}1,540 \\
1,600 \\
14,900 \\
28,600\end{array} \mid$ & $\begin{array}{l}141 \\
116 \\
114 \\
102\end{array}$ & $\begin{array}{l}67 \\
78 \\
88 \\
95\end{array}$ & $\begin{array}{r}1,800 \\
1,550 \\
15,200 \\
29,400\end{array}$ & $\begin{array}{l}141 \\
134 \\
116 \\
102\end{array}$ & $\begin{array}{l}73 \\
63 \\
88 \\
96\end{array}$ & $\begin{array}{l}1,680 \\
1,450 \\
14,200 \\
29,400\end{array}$ & $\begin{array}{l}140 \\
117 \\
113 \\
102\end{array}$ & $\begin{array}{l}73 \\
70 \\
87 \\
80\end{array}$ \\
\hline
\end{tabular}

1919.

\begin{tabular}{|c|c|c|c|c|c|c|c|c|c|c|c|c|c|c|c|c|}
\hline \multirow[b]{2}{*}{ Station. } & \multirow{2}{*}{ 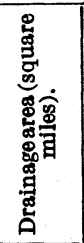 } & \multicolumn{3}{|c|}{ May 25.} & \multicolumn{3}{|c|}{ May 26.} & \multicolumn{3}{|c|}{ May 27.} & \multicolumn{3}{|c|}{ May 28.} & \multicolumn{3}{|c|}{ May 29.} \\
\hline & & 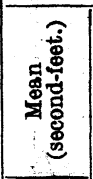 & 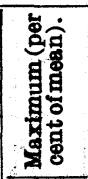 & 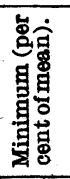 & 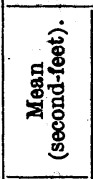 & 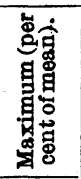 & 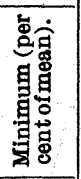 & 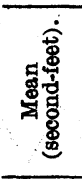 & 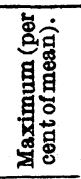 & 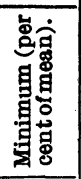 & 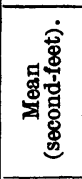 & 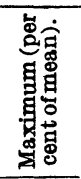 & 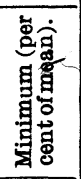 & 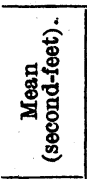 & 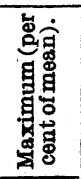 & 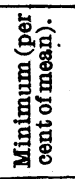 \\
\hline $\begin{array}{l}\text { Uncompahgre River at Ouray, Colo } \ldots \ldots . . \\
\text { Uncompeahgre River below Ouray, Colo.... } \\
\text { Castle Creor near Aspen, Colo } \\
\text { Fryingpan Creek at Thomasvilie, Colo........ } \\
\text { Roaring Fork at Gllenwood Springs, Colo... } \\
\text { Colorado River at Glenwood Springs, Colo. }\end{array}$ & $\begin{array}{r}44 \\
76 \\
72 \\
175 \\
1,450 \\
4,520\end{array}$ & $\begin{array}{r}335 \\
503 \\
3220 \\
1,260 \\
5,700 \\
11,200\end{array}$ & $\begin{array}{l}131 \\
126 \\
112 \\
110 \\
110 \\
102\end{array}$ & $\begin{array}{l}81 \\
82 \\
83 \\
84 \\
90 \\
98\end{array}$ & $\begin{array}{r}399 \\
590 \\
340 \\
1,350 \\
6,340 \\
11,400\end{array}$ & $\begin{array}{l}137 \\
147 \\
110 \\
103 \\
112 \\
103\end{array}$ & $\begin{array}{l}80 \\
78 \\
87 \\
85 \\
\mathbf{9 0} \\
\mathbf{9 6}\end{array}$ & $\begin{array}{r}488 \\
771 \\
340 \\
1,390 \\
6,400 \\
11,800\end{array}$ & $\begin{array}{l}127 \\
124 \\
120 \\
118 \\
110 \\
103\end{array}$ & $\begin{array}{l}81 \\
84 \\
85 \\
85 \\
90 \\
97\end{array}$ & $\begin{array}{r}509 \\
725 \\
\mathbf{3 5 8} \\
\mathbf{1}, 390 \\
\mathbf{6 , 6 4 0} \\
\mathbf{1 1}, 600\end{array}$ & $\begin{array}{l}122 \\
121 \\
103 \\
114 \\
110 \\
102\end{array}$ & $\begin{array}{l}79 \\
81 \\
85 \\
88 \\
91 \\
99\end{array}$ & $\begin{array}{r}537 \\
811 \\
348 \\
1,410 \\
6,840 \\
12,000\end{array}$ & $\begin{array}{l}120 \\
121 \\
115 \\
119 \\
111 \\
102\end{array}$ & $\begin{array}{l}80 \\
84 \\
86 \\
85 \\
89 \\
97\end{array}$ \\
\hline
\end{tabular}


The drainage areas above the measuring points on the streams shown for the seven days in 1918 range from 76 to 4,520 square miles. The average maximum discharge ranged from 139 per cent of the mean for the smallest area to 103 per cent for the largest, and the average minimum discharge from 72 to 95 per cent. The drainage areas considered in the comparison for the five days in 1919 range from 44 to 4,520 square miles. The average maximum discharge ranged from 127 to 102 per cent of the mean for the smallest and largest areas, respectively, and the average minimum discharge ranged from 80 to 97 per cent. The range of percentages was smaller in 1919 on account of the smaller total discharge and the colder spring. The tabulation also shows the possible errors that may be made by basing computations of daily discharge upon one gage reading. The mean of two daily readings taken nearly 12 hours apart will be very much nearer the true mean for the day, as will be seen by inspecting figures 13 to 16 .

\section{UNIT RUN-OFF.}

Stations in the same basin.-As snowfall, which is the chief source of run-off in the mountain streams, increases with altitude, it is evident that in general the upper portions of a drainage basin have a greater run-off per unit of area drained than the lower portions.' It is not possible to show directly the varying run-off from different altitudes, but a comparison of the records for different stations on the same stream shows that the smallest unit run-off occurs at the lowest altitude. The table on page 66 shows three comparisons between stations in the same basin for practically the same years, together with an analysis of each drainage area, showing percentages above different altitudes. The figures represent the natural run-off, as allowances have been made for the few diversions that affect the run-off.

Laramie River at Glendevey, Colo., with 13 per cent of its drainage area above an altitude of 11,000 feet, has a mean annual run-off of 880 acre-feet to the square mile. At the station near Woods, Wyo., only 3 per cent of the drainage area is above 11,000 feet, and the remaining 97 per cent, of which 38 per cent is below 9,000 feet, contributes so small a run-off that the unit run-off for the entire drainage area is reduced to 474 acre-feet. Similarly Deep Creek, a tributary of Rock Creek, with its entire drainage area between 10,000 and 11,000 feet, has a run-off of 1,340 acre-feet to the square mile, but Rock Creek itself, which has only 43 per cent of its drainage area above 10,000 feet, has a run-off of only 804 acre-feet to the square mile. South Boulder Creek near Rollinsville, with 94 per cent of its drainage area above 9,000 feet and 13 per cent above 11,000 feet, has a mean annual run-off of 1,180 acre-feet to the square mile. At Eldo- 
rado Springs, where only 56 per cent of the drainage area is above 9,000 feet and 9 per cent above 11,000 feet, the lower areas contribute so small a run-off that the unit run-off for the entire drainage area is reduced to 496 acre-feet.

Comparison of unit run-off for stations in the same drainage basins.

\begin{tabular}{|c|c|c|c|c|c|c|c|c|}
\hline \multirow[b]{2}{*}{ Station. } & \multicolumn{5}{|c|}{ Drainage area. } & \multicolumn{2}{|c|}{$\begin{array}{c}\text { A verage annual } \\
\text { run-off (acre- } \\
\text { feet). }\end{array}$} & \multirow[b]{2}{*}{$\begin{array}{l}\text { Yearscovered } \\
\text { by records. }\end{array}$} \\
\hline & $\begin{array}{c}\text { Total } \\
\text { (square } \\
\text { miles). }\end{array}$ & $\begin{array}{l}\text { Per } \\
\text { cent } \\
\text { above } \\
9,000 \\
\text { feet. }\end{array}$ & $\begin{array}{l}\text { Per } \\
\text { cent } \\
\text { above } \\
10,000 \\
\text { feet. }\end{array}$ & $\begin{array}{l}\text { Per } \\
\text { cent } \\
\text { above } \\
11,000 \\
\text { feet. }\end{array}$ & $\begin{array}{l}\text { Per } \\
\text { cent } \\
\text { above } \\
12,000 \\
\text { feet. }\end{array}$ & Total. & $\begin{array}{l}\text { Per } \\
\text { square } \\
\text { mile. }\end{array}$ & \\
\hline \multicolumn{9}{|l|}{ Laramie River basin. } \\
\hline $\begin{array}{l}\text { Laramie River at Glendevey, } \\
\text { Colo. }\end{array}$ & 102 & 74 & 24 & 13 & 1 & 89,700 & 880 & \\
\hline $\begin{array}{l}\text { Laramie River near Jelm, } \\
\text { Wyo. } \\
\text { Laramie River near Woods, } \\
\text { Wyo. }\end{array}$ & $\begin{array}{l}293 \\
409\end{array}$ & $\begin{array}{l}48 \\
35\end{array}$ & $\begin{array}{r}10 \\
7\end{array}$ & 3 & $\begin{array}{l}.3 \\
.2\end{array}$ & $\begin{array}{l}173,000 \\
194,000\end{array}$ & $\begin{array}{l}590 \\
474\end{array}$ & $\begin{array}{l}1905, \quad 1911- \\
1918 . \\
1912-1918 .\end{array}$ \\
\hline Rock Creek basin. & & & & & & & & \\
\hline Deep Creek near Arlington, & 3.7 & 100 & 100 & 0 & 0 & 4,970 & 1,340 & $1915,1917$. \\
\hline $\begin{array}{l}\text { Rock Creek near Arlington, } \\
\text { Wyo. }\end{array}$ & 70 & 85 & 43 & 0 & 0 & 56,200 & 804 & $1915,1917$. \\
\hline South Boulder Creek basin. & & & & & & & & 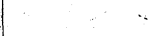 \\
\hline $\begin{array}{l}\text { South Boulder Creek near } \\
\text { Rollinsville, Colo. }\end{array}$ & 39 & 94 & 62 & 13 & 2 & 45,400 & 1,180 & $1911-1917$. \\
\hline $\begin{array}{l}\text { South Boulder Creek at El- } \\
\text { dorado Springs, Colo. }\end{array}$ & 115 & 56 & 28 & 9 & 1 & 57,200 & 496 & $1911-1917$. \\
\hline
\end{tabular}

Stations in different basins.-The unit run-off of mountain streams varies not only with the altitude, as shown in the preceding paragraphs, but also with the presence or absence of higher mountain masses near by yet outside the drainage basin itself.

The following table, compiled from records of mountain streams at stations above diversions, or where known diversions have been accounted for, shows an analysis of altitudes for each drainage area, the total run-off, and the mean annual run-off per square mile for each stream. The analysis of altitudes is based on measurements made on topographic maps.

In this table the stations are arranged geographically, beginning at the northwest corner of Wyoming and following south along the west side of the main mountain masses, then taking the stations in the interior mountain ranges, and finally those on the eastern slope of the front range, facing the great plains. This arrangement brings out the fact that in general the streams which drain the western ranges have a much higher unit run-off than those which drain the interior and eastern ranges. 
Unit run-off of mountain streams.

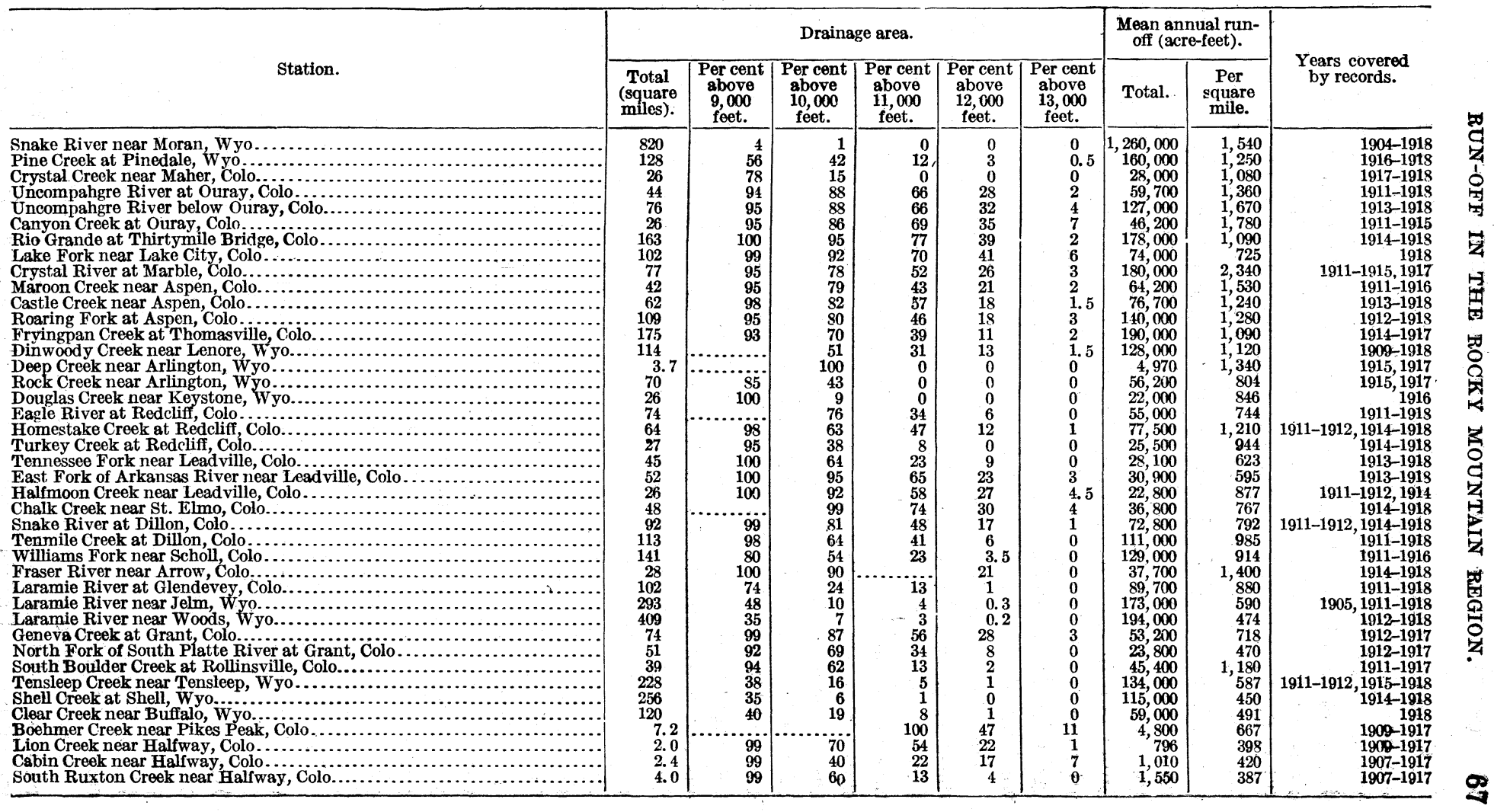


The most striking comparison shown in the table is that between the station on Snake River near Moran, Wyo., and those on the eastern slope of Pikes Peak, in Colorado. At the Moran station the drainage area is practically all below 10,000 feet and the annual runoff is 1,540 acre-feet to the square mile; on Boehmer Creek near Pikes Peak, Colo., whose drainage area lies between 11,000 and 14,000 feet, the mean run-off is 667 acre-feet to the square mile, and the other streams in that vicinity, with the greater part of their drainage areas between 10,000 and 14,000 feet, have a run-off of approximately 400 acre-feet to the square mile. The Snake River basin above the upper end of the Teton Range has no large mountain masses of high altitude to the west, but Pikes Peak, .although detached from the main mountain mass, has the entire Rocky Mountain system to the west but faces the plains on the east.

The difference in run-off on different sides of a large mountain mass is shown by the comparison between the Uncompahgre, the Rio Grande, and Lake Fork, which drain one of the largest mountain masses in the Rockies. The Uncompahgre drains the northwestern slope, the Rio Grande the eastern slope, and Lake Fork the northeastern slope. The altitude of these drainage areas is similar, from 32 to 41 per cent lying above 12,000 feet and from 2 to 6 per cent above 13,000 feet, yet the run-off decreases from 1,670 acre-feet to the square mile on the northwestern slope to 1,090 acre-feet on the eastern slope and to 725 acre-feet on the northeastern slope. The figure for the northeastern slope, being based on records for only one year (1918), is somewhat uncertain, although in the Uncompahgre drainage basin the run-off for that year is 95 per cent of the mean for six years. The highest run-off given in the table is 2,340 acre-feet for Crystal River at Marble, Colo., whose drainage area is not at an excessively high altitude, being surpassed by those of several other streams on which the run-off is considerably lower. An explanation of this phenomenon is found in the fact that west of the mountain range whose eastern slope is drained by Crystal River there are no other mountain masses higher than the flat-topped mesas of western Colorado.

The comparatively high run-off of Deep Creek near Arlington (1,340 acre-feet) is due to altitude and position, of which position is relatively more important. The drainage area lies on the flat top of the Medicine Bow Mountains. To the east is the main bulk of the range, one small area of which reaches an altitude of 11,000 feet, but to the west the nearest range approaching 10,000 feet in altitude is the Wasatch Range, in eastern Utah, and to the northwest the nearest range is the Wind River Mountains.

A noticeable effect of altitude upon run-off is shown by the comparison between Eagle River and Homestake Creek. Eagle River, with 6 per cent of its drainage area above 12,000 feet and 34 per cent 
above 11,000 feet, has a run-off of 744 acre-feet to the square mile; Homestake Creek, which drains an area joining that of the Eagle on the west and which has 12 per cent of its area above 12,000 feet and 47 per cent above 11,000 feet, shows a run-off of 1,210 acre-feet.

South Boulder Creek at Rollinsville, Colo., presents an apparent exception to the generally low run-off of streams draining the eastern ranges. Its drainage area, 2 per cent of which is above 12,000 feet, lies on the east side of the Continental Divide, and its run-off is 1,180 acre-feet. This may be explained by the fact that west of this part of the divide lies the comparatively open region of Middle Park, and west of that no mountain masses as high as the divide itself.

The foregoing comparisons show that in th $\$$ Rocky Mountain region unit run-off varies not only with altitude but also with the location of the drainage basin in reference to mountan masses near by on the west, as the storms coming from the west apparently carry more moisture and precipitate the greater part of their moisture on the first ranges they strike, the amount precipitated becoming less as each succeeding range is reached.

\section{WINTER RUN-OFW.}

Below timber line.-The winter run-off of nountain streams, being wholly dependent upon ground water, gradually decreases and reaches a minimum just before the melting of the snow in the spring. The higher the altitude drained the less is the likelihood of temporary rises of temperature being sufficient to affect the discharge. Sudden drops in temperature at the beginning of the winter have a decided temporary effect on the run-off, but the effect of similar drops later in the winter is much less. Figure 17 shdws four hydrographs of streams ranging in drainage area from 8,080 to 48 square miles for the winter of 1918-19. The hydrograph for Colorado River at Glenwood Springs, Colo. (drainage area 4,520 square miles), shows that the flow dropped suddenly during the later part of November as a result of the low temperature, then rose with the temperature, and again fell more gradually, registering a minimum on December 25 as a result of the low temperature at that time. After rising again the run-off gradually decreased for the remainder of the winter until early in March, when the rising temperatures caused the snow at the lower altitudes to melt and increase the run-off. The daily fluctuations were due to the operation of the Shoshone power plant, 7 miles upstream from the station. The hydrograph for Big Horn River at Thermopolis, Wyo. (drainage area 8,080 square miles), has the same general characteristics and shows the decided effect of sudden drops and rises in temperature at the beginning of the winter but the very slight effect of similar changes later in the winter until March, when the temperature rose sufficiently to melt the snow at the lower altitudes. The hydrograph for Tensleep Creek near Tensleep, Wyo. 


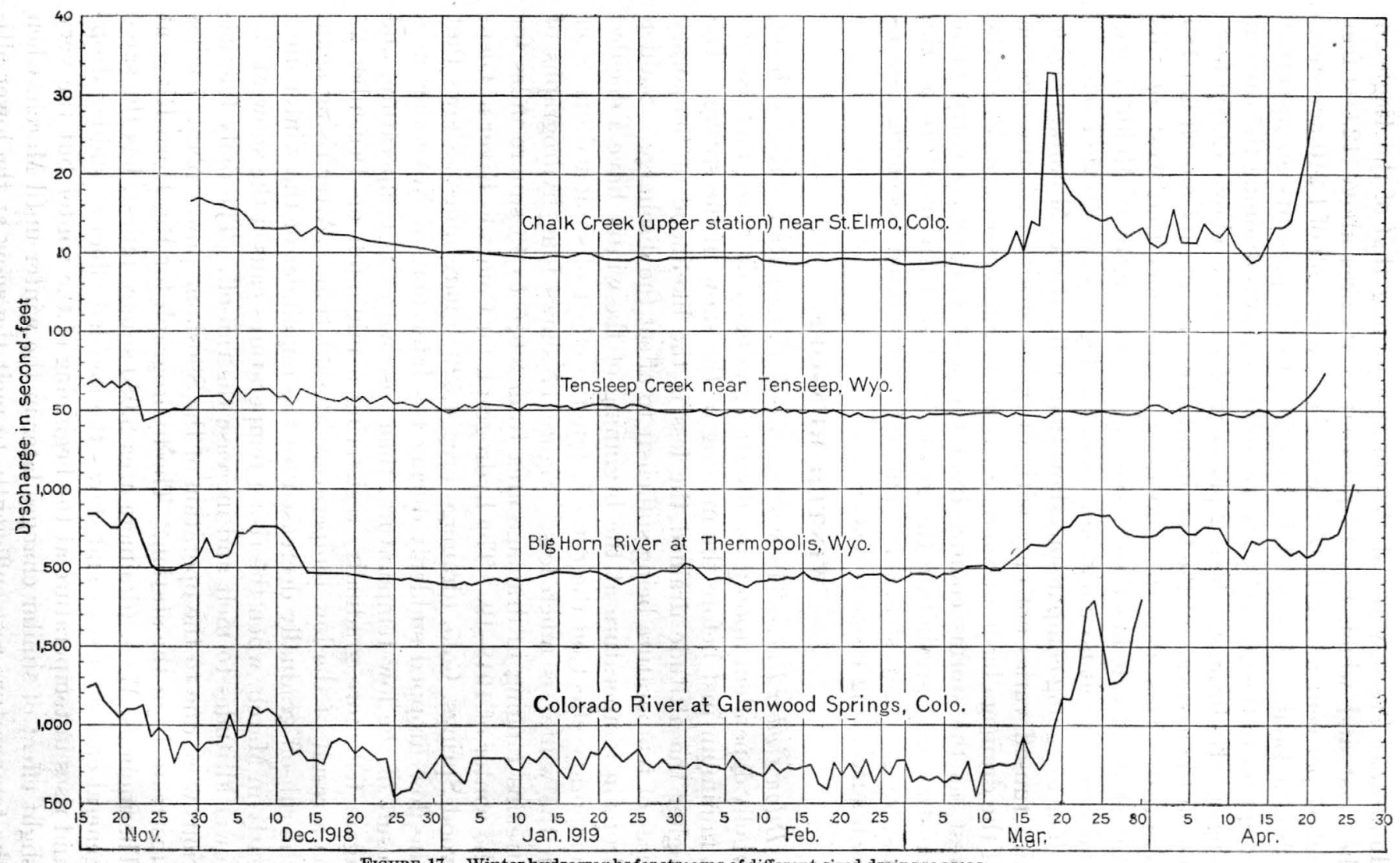


(drainage area 228 square miles), shows that the only effect of temperature on this stream was at the beginning of the winter, as for the greater part of the season the flow was almost constant, with a slow decrease. The upper station on Chalk Creek near St. Elmo, Colo. (drainage area 48 square miles), is at so high an altitude that changes in temperature during the winter had little effect on the run-off, being insufficient to cause the snow to melt.

Above timber line.-In this region the altitude of timber line (the upper limit at which timber grows) increases from 10,000 feet in northern Wyoming to 12,000 feet in central Colorado. Above this line the ground is covered with short grass and the soil is generally thin and at the higher altitudes gives way entirely to the bare rocks of the mountain peaks. Although the snowfall is very heavy in these areas, the scantiness of the soil does not afford any considerable reservoir for storing ground water. Observations made by the United States Forest Service show that at the Wagonwheel Gap experiment station, where the timber line is at 12,000 feet, the mean soil temperature at depths of 1 foot and 4 feet is $33^{\circ} \mathrm{F}$. At a depth of 1 foot the soil is frozen on an average seven and one-half months of the year, and at a depth of 4 feet it is frozen five months of the year. Similar observations on Pikes Peak, where the timber line is likewise at 12,000 feet, show that the soil there at a depth of 1 foot remains frozen six months each year. As the temperature decreases with an increase in altitude, it is evident that above the lowest altitude reached by timber line the soil remains frozen for a longer period and the frost reaches a greater depth. The ground water is the only source of supply for streams in these areas during the winter, and the small amount of water in the soil remains mostly in the form of ice, little if any of it reaching the streams.

Records of winter run-off for stations at or above timber line in this region are very meager, but such as are available show the run-off to be practically zero. During the winter of 1914-15 Mr. S. C. Hulse, consulting engineer, maintained three gaging stations, of which one had its entire drainage area above timber line and the other two half their areas above timber line. These stations were visited weekly from November to March by a hydrographer, who found ${ }^{1}$ that at the upper station on Spruce Creek near Breckenridge, with an area of 1.7 square miles wholly above timber line, the flow ceased entirely at the end of November and did not begin again until spring. The lower Spruce Creek station, with a drainage area of 3.4 square miles, had a winter flow decreasing from 0.25 second-foot in December to 0.15 second-foot in March, or from 0.07 to 0.03 foot to the square mile. Similarly Crystal Creek near Breckenridge, with a drainage area of 2 square miles, had a winter flow decreasing from 0.10 to 0.05 second-foot to the square mile.

I U. S. Geol. Survey Water-Supply Paper 409, pp. 77-79, 1918. 


\section{INDEX.}

Acknowledgments for aid

Arkansas River at Salida, Colo., relation of temperature to discharge of...... 57-58

Arnett, Okla., well of county courthouse at.. wells northwest of

Beaver, Okla., precipitation at

40

Chambers, Alfred A., analysis by

Coeur d'Alene Lake, Idaho, controversy concerning

description of.

inflow and outflow of.

influence of storage on level of ........... 15-18

lowering the outlet of, feasibility of...... 25

interference with navigation by...... 25

purposes to be served by ........... 21-23

overflow lands near, value of............ $\quad$ 7-8

transportation on.................... 7

use of, for storage water................ 1

parties in interest in.............. 20-21

value of, for development of water power. $\quad 8-9$

water level of......................... 6-7

Coeur d'Alene Lake region, Idaho, diking of lands in, commercial aspect of ...

diking lands in, effects of.............. 26-27

public interest in .................. 29-30

field work in .......................... 2

lead deposited on lands in.............. 8

reconciling of interests in................ 30-31

settlement of ......................... 9-10

water-logging of lands in............. 18-20, 28

diking and draining necessary to relieve......................... 26, 28

Coeur d'Alene River, Idaho, deposition of soil by

Colorado River, high-water fluctuations of... 60,64

Davenport, R. W., Coeur d'Alene Lake, Idaho, and the overflow lands... 1-31

Fargo, Okla., well at.

Follansbee, Robert, Some characteristics of run-off in the Rocky Mountain region.

55-71

Foster, Margaret D., analysis by.

Gage, Okla., flowing well near........ 44-46,50,51 flowing well near, plates showing....... 44 public water supply of...............42,50,51 well 3 miles south of, quality of water in. 50,51

Gage, Okla., and vicinity, artesian conditions in the "Red Beds". in........... 48

climate of........................... 40-41 feasibility of irrigation in . . ........ 33-34, 51-53 geography of. 34-37
Gage, Okls, and vicinity, geology of Page. ground-water investigation in........... 33 quality of waters in................ 38, 50-51

"Red Beds" in, features of .............. 37-39 springs in............................ 44 Tertiary and Quaternary deposits in..... 39 water from alluvium in................. 41-42 water from Permian "Red Beds" in..... 44-48 water from Tertiary deposits in.......... 42-44

Gate, Okls., well near.................... 47

Guarantee Development Co., well of, near Gage, Okla............. 44-46,50, 51

Herrick, Fred, acknowledgment to......... 2

Holmes, C. H., acknowledgment to......... 33

Home Producers Oil \& Gas Co., acknowledgment to....................

well drilled by........................ 47,48

Idaho, northern, climate of............... 5 5-6

Jessup, L. T., acknowledgment to.......... 2

Kidwell, C. H., analysis by.............. $\quad 50$

Land, values of, for agriculture and for waterpower storage compared......... 28-30

Lipscomb, Okla., well near................ 47

May, Okla., well southwest of............. $\quad 47$

Minton, C. J., acknowledgment to.......... 33

Mullan, Capt. John, cited................ 4-5, 21

Mutual, Okla., precipitation at............ $\quad 40$

Noble, T. A., estimate of, on enlarging the channel of Spokane River........ 22

Nye, Capt. John A., acknowledgment to..... 2

Parker, M. S., acknowledgment to.......... 2 2

Post Falls,Idaho, building of dams at ....... 10,13 elevations of dams at, diagram showing.. $\quad 10$ operation of dams at.................. 13-14

Power, hydroelectric, development of, on Spokane River................ 8-9

Roaring Fork, Colo., diurnal discharge, fluctuations of...............6 60,61, 63, 64

Run-off, diurnal fluctuations of............. 59-65 maximum, relation between rate of melting of snow and............... 58-59 relations of temperature and discharge shown in................... 57-65 unit, calculation of................... $65-68$

Run-off of Rocky Mountain streams, common characteristics of........... 55

St. Joe River, Idaho, deposition of soil by... 3 description of valley of................ 4-5 drainage district on, proposed........... 8 
St. Maries, Idaho, temperature and precipitation recorded at.

Schultz, C. D., wells, on farm of.

Sowers, R. M., acknowledgment to

Spokan River, Idaho and Wash tion of

discharge of, at Spokane, Wash.......... elevation of dams on, diagram showing flow records of.

measurements and materials of bed of... minor improvements fessible in. profile and cross sections of proposed improvement of, benefits to be expected from ...................

damages possible from................

excavation necessary for..............

Spokane River basin, Idaho and Wash., map of..............................

Tensleep Creek, Wyo., diurnal discharge, fluctuations of.
Page. Thompson, David G., Ground water for irr-
gation near Gage, Okla........ 33-53

$16-17$

Uncompahgre River, Colo., high-water and discharge fluctuations of... 58, 59, 61, 64

Washington Water Power Co., acknowledgment to........................

acquirement of water rights by.... 10-12, 27-28

enlargement of the channel of Spokane River proposed by.............. 22

use of Coeur d'Alene Lake by............ 1

Waters, classification of................. 48-50

Winter run-off of mountain streams, fluctuation of......................69-71

Wolf Creek, Okla., irrigation wells in valley of............................ 34,42

quality of water of.....................5,51

Woodward, Okla., precipitation at......... 40

temperature at.......................... $\quad \mathbf{4 1}$

well southwest of.................... 47

62,64 